\title{
Development of Rat Embryos at the 1- and 2-Cell Stage in Modified HECM-1 Medium after Exposure to a Medium that Contained Phosphate
}

\author{
Hiromichi MATSUMOTO and Shichiro SUGAWARA \\ Faculty of Agriculture, Tohoku University, Sendai-shi 981, Japan
}

\begin{abstract}
The development of rat embryos after exposure to a medium that contained phosphate was examined. After exposure to a medium that contained phosphate, embryos were washed 10 times in watch glasses with $1 \mathrm{ml}$ of modified HECM-1. Then they were rinsed 8 times with $100-\mu \mathrm{l}$ droplets of the same medium in an attempt to bring the concentration of phosphate after washing below $1.0 \mathrm{fM}$. After exposure for 0,10 and $20 \mathrm{~min}$ to $\mathrm{Ca}^{2+}-\mathrm{Mg}^{2+}$ and substrate-free Dulbecco's Phosphate Buffered Saline (D-PBS $(-))$, the development rates of 1-cell embryos to the blastocyst stage were $44 \%, 39 \%$ and $52 \%$, respectively, and the mean numbers of blastomeres in the blastocysts were 20.017 .7 and 19.4, respectively. After exposure for 0, 30 and $60 \mathrm{~min}$ to $\mathrm{mHECM}-1$ supplemented with $1.19 \mathrm{mM} \mathrm{KH}_{2} \mathrm{PO}_{4}$, the development rates to the blastocyst stage from the 1-cell stage were $47 \%, 60 \%$ and $55 \%$, respectively, and mean numbers of blastomeres in the blastocysts were $16.3,16.6$ and 15.5 , respectively. By contrast, $93 \%$ to $100 \%$ of 2 -cell embryos developed to the blastocyst stage. In each six experiments, the development of embryos after breif exposure to phosphate was not significantly different from the group witout exposure. When 2-cell embryos were exposed to phosphate for $15 \mathrm{~h}$ and $18 \mathrm{~h}$, the rate of development to blastocysts decreased markedly to $60 \%$ and $22 \%$, respectively. Embryonic development was completely inhibited by exposure to phosphate for more than $21 \mathrm{~h}$.

Key words: Rat embryo, Developmental block, Phosphate, Exposure time.
\end{abstract}

(J. Reprod. Dev. 41: 263-269, 1995)

M ammalian embryos cultured in vitro cease development at a specific stage characteristic of each species. For example, rat embryos cease development at the 2-cell stage. This phenomenon is known as the "developmental block" and it has been overcome in embryos of livestock and experimental animals without in rat and hamster [1].

Recently, development of hamster 2-cell embryos to the blastocyst stage was achieved in vitro using hamster embryo culture medium-1 (HECM$1)$, which is free of phosphate and glucose [2].

Accepted for publication: June 10, 1995

Correspondence: $\mathrm{H}$. Matsumoto
Reportedly HECM-1 can also overcome developmental block in rat embryos [3] and concentrations of phosphate lower than $10 \mathrm{nM}$ in this medium do not inhibit the rat embryonic development [4]. However, the reason phosphate causes mechanism of rat embryos to cease developing at the 2-cell stage is unclear, because phosphate is present in the culture medium from the start of cultivation. For this reason, timing applications of phosphate prior to the developmental block will help to identify the effects of phosphate on embryonic development.

In this study, the development of rat embryos was examined at the 1- or 2-cell stage after collecting them and washing them in $\mathrm{Ca}^{2+}, \mathrm{Mg}^{2+}$, and 
substrate-free Dulbecco's Phosphate Buffered Saline (D-PBS ( -$)$ ). The embryos were washed again after their exposure to a medium that contained phosphate. Furthermore, the development of 1- or 2-cell stage rat embryos was examined for various time intervals subsequent to exposure to D-PBS ( - ) or modified HECM-1 supplemented with 1.19 $\mathrm{mM}$ phosphate. The duration of exposure to phosphate was extended to examine the inhibitory effect at the 2-cell stage.

\section{Materials and Methods}

\section{Animals}

Wistar rats bred and maintained in The Laboratory of Animal Reproduction at Tohoku University were used for the experiments. The sexual cycle of females was monitored from vaginal smears. They were caged with males for mating at proestrus. The next morning was considered as day 1 of pregnancy when a vaginal plug and/or sperm in the vaginal smear was detected. Lights were kept on between $0600 \mathrm{~h}$ and $1800 \mathrm{~h}$ daily.

\section{Cultivation and evaluation of embryos}

All collected 1-cell or 2-cell stage embryos were subjected either to washing and culture (Experiment 1) or phosphate to exposure, washing, and culture (Experiment 2-5). The culture medium used was modified HECM-1 that contained $4 \mu \mathrm{g} /$ $\mathrm{ml}$ phenol red, $100 \mathrm{IU} / \mathrm{ml}$ penicillin, $0.1 \mathrm{mg} / \mathrm{ml}$ streptomycin and $0.5 \mathrm{mg} / \mathrm{ml}$ polyvinyl alcohol. Experiments 4 and 5, where the effects of $\mathrm{KH}_{2} \mathrm{PO}_{4}$ and the duration of exposure were examined, 5.56 $\mathrm{mM}$ glucose was added to the culture medium because glucose promotes the rat embryonic development [4]. The osmolarity of the medium was checked in every experiment. Embryos were collected by flushing oviducts. One-cell embryos were freed of cumulus cells by treating them with $0.1 \%$ hyaluronidase in mHECM-1 or in D-PBS $(-)$. Embryos were placed in $100 \mu \mathrm{l}$ of medium under a layer of mineral oil and cultured in a humidified atmosphere of $5 \% \mathrm{CO}_{2}$ in air at $37.5 \mathrm{C}$. In experiments 3, 4 and 5, the number of blastomeres in blastocysts was estimated by Giemsa staining after fixation as follows: a) they were treated with $1 \%$ trypsin in D-PBS ( - ) for $40 \mathrm{sec}$ at $37 \mathrm{C}$; b) incubated in $60 \%$ fetal calf serum for $15 \mathrm{~min}$ at room temperature; c) fixed in a mixture of methanol, ace- tic acid and distilled water (5:1:4, v/v) for 5 to 7 min at room temperature; d) mounted on a deproteinized and defatted, clean, glass slide; and e) fixed again by gentle immersion in a mixture of methanol and acetic acid $(3: 1, \mathrm{v} / \mathrm{v})$.

\section{Experiment 1}

Effects of different flushing media on the development of the 1-cell embryo to the blastocyst stage were examined. One-cell embryos were collected at $1800 \mathrm{~h}$ on day 1 by flushing oviducts with mHECM-1 or D-PBS (-). After flushing, embryos were washed twice with flushing media in watch glasses and rinsed 2 to 3 times with 100- $\mu$ l droplets of mHECM-1. The total time required for flushing with mHECM-1 and D-PBS (-) was 25 min and $30 \mathrm{~min}$, respectively.

\section{Experiment 2}

The effect of careful washing on embryonic development subsequent to flushing with D-PBS ( - ) was tested. One-cell embryos were collected at $1700 \mathrm{~h}$ on day 1. After flushing oviducts with DPBS ( - ), embryos were washed 10 times in watch glasses with $1 \mathrm{ml}$ each time of $\mathrm{mHECM}-1$ and then rinsed 8 times in 100- $\mu$ ldroplets of the same medium. On the basis of these washes, concentration of phosphate that was carried to the culture droplets should have been lower than $1.0 \mathrm{fM}$. In the control group, flushing and washing with mHECM-1 were performed as in Experiment 1. The total time required for flushing with $\mathrm{MHECM}$ 1 was $30 \mathrm{~min}$, and the total time for flushing with D-PBS ( - ) and washing with MHECM-1 was 35 min.

\section{Experiment 3}

Effects of exposure to D-PBS (-) on development in vitro of 1-cell embryos were examined. One-cell embryos were collected at $1600 \mathrm{~h}$ on day 1 by flushing, washing with D-PBS $(-)$ and exposed to the same medium for 10 or $20 \mathrm{~min}$ at 37.5 C. After exposure, the embryos were washed with mHECM-1 as in Experiment 2. In the control experiment, flushing and washing with MHECM-1 were performed in the same way as in Experiment 1.

\section{Experiment 4}

Conventional media (e.g. the media described by Whitten [5], Biggers [6] and Brinster [7]) con- 
tain $1.19 \mathrm{mM} \mathrm{KH}_{2} \mathrm{PO}_{4}$, and $\mathrm{CZB}$ medium contains $1.18 \mathrm{mM} \mathrm{KH}_{2} \mathrm{PO}_{4}$ [8]. But D-PBS ( - ) contains 9.55 $\mathrm{mM}$ phosphate. Therefore, the effects of exposure to $\mathrm{mHECM}-1$ supplemented with $1.19 \mathrm{mM} \mathrm{KH}_{2} \mathrm{PO}_{4}$ on 1- and 2-cell embryonic development were examined. One-cell embryos were collected at 1600 $\mathrm{h}$ on day 1 and 2-cell embryos were collected at $1100 \mathrm{~h}$ on day 2 by flushing with mHECM-1. Embryos were exposed to the medium that contained phosphate for 30 or $60 \mathrm{~min}$ at $37.5 \mathrm{C}$.

\section{Experiment 5}

Development of rat embryos was blocked at the 2-cell stage by the exposure to the medium that contained phosphate. However, when the exposure was brief, development was not inhibited. Therefore, the duration of exposure was extended to examine the inhibitory effect of phosphate at the 2-cell stage. The embryos used in Experiment 5 were 2-cell embryos collected at $1100 \mathrm{~h}$ on day 2 by flushing with mHECM-1. Embryos were exposed to the mHECM-1 medium supplemented with $1.19 \mathrm{mM} \mathrm{KH}_{2} \mathrm{PO}_{4}$ for 3, 6, 9, 12, 15, 18, 21 or $24 \mathrm{~h}$ at $37.5 \mathrm{C}$.

\section{Statistical analysis}

Developmental rates were compared by the chisquare test. Numbers of blastomeres in blastocysts were compared by Student's $t$-test.

\section{Results}

\section{Experiment 1}

When 1-cell embryos were flushed from oviducts with D-PBS ( - ), the rate of development beyond the 4-cell stage was significantly lower than in controls $(\mathrm{P}<0.05)$, and no embryos developed to the blastocyst stage (Table 1).

\section{Experiment 2}

The rates of development of rat embryos beyond the 4-cell stage and to blastocysts did not differ significantly between flushing with MHECM-1 or flushing with D-PBS ( - ) (Table 2).

\section{Experiment 3}

The rates of development of rat 1-cell embryos beyond the 4-cell stage and to blastocysts, and the number of blastomeres did not differ significantly among the 3 exposure times of 0,10 and $20 \mathrm{~min}$ (Table 3).

\section{Experiment 4}

Cultivation from the 1- and 2-cell stage following exposure for 30 or $60 \mathrm{~min}$ to $1.19 \mathrm{mM}$ phosphate

Table 1. The effect of flushing media used for collection of embryos on development in vitro of rat 1-cell embryos

\begin{tabular}{|c|c|c|c|c|}
\hline \multirow[b]{2}{*}{$\begin{array}{l}\text { Flusing } \\
\text { medium }\end{array}$} & \multirow{2}{*}{$\begin{array}{c}\text { No. of } \\
\text { 1-cell embryos } \\
\text { examined }\end{array}$} & \multirow{2}{*}{$\begin{array}{l}\text { No. of embryos } \\
\text { developed to } \\
\text { 2-cell stage }\end{array}$} & \multicolumn{2}{|c|}{ No. and $(\%)$ of embryos developed to: } \\
\hline & & & $\begin{array}{c}\geq 4 \text {-cell stage at } \\
72 \mathrm{~h}\end{array}$ & $\begin{array}{c}\text { blastocysts at } \\
120 \mathrm{~h}\end{array}$ \\
\hline mHECM-1 & 44 & 42 & $39\left(93^{a}\right)$ & $30 \quad\left(71^{\mathrm{a}}\right)$ \\
\hline D-PBS ( - ) & 40 & 32 & $3(9 b)$ & $0\left(0^{b}\right)$ \\
\hline
\end{tabular}

The numbers in parentheses indicate percentages relative to the initial number of 2-cell embryos. $\mathrm{a}, \mathrm{b}$ Values with different superscripts within each column differ significantly $(\mathrm{P}<0.05)$.

The osmolarity of mHECM-1 was 283 mOsm.

Table 2. The effect of washing with mHECM-1 on development in vitro of rat 1-cell embryos collected with D-PBS (-)

\begin{tabular}{|c|c|c|c|c|}
\hline \multirow{2}{*}{$\begin{array}{l}\text { Flushing } \\
\text { medium }\end{array}$} & \multirow{2}{*}{$\begin{array}{c}\text { No. of } \\
\text { 1-cell embryos } \\
\text { examined }\end{array}$} & \multirow{2}{*}{$\begin{array}{l}\text { No. of embryos } \\
\text { developed to } \\
\text { 2-cell stage }\end{array}$} & \multicolumn{2}{|c|}{ No. and $(\%)$ of embryos developed to: } \\
\hline & & & $\begin{array}{c}\geq 4 \text {-cell stage at } \\
72 \mathrm{~h}\end{array}$ & $\begin{array}{c}\text { blastocysts at } \\
120 \mathrm{~h}\end{array}$ \\
\hline mHECM-1 & 31 & 31 & $29(94)$ & $9(29)$ \\
\hline D-PBS ( - ) & 32 & 32 & $28(88)$ & $7(22)$ \\
\hline
\end{tabular}

The numbers in parentheses indicate percentages relative to the initial number of 2-cell embryos. The osmolarity of mHECM-1 was 285-286 mOsm. 
did not affect the development of embryos. Neither development nor numbers of blastomeres in blastocysts differed significantly among the 3 exposures of 0,30 and $60 \mathrm{~min}$ (Tables 4 and 5).

\section{Experiment 5}

As the duration of exposure to phosphate increased, rates of development decreased significantly (Table 6; $\mathrm{P}<0.05$ ). Embryos at the 2cell stage that had been exposed to mHECM-1 supplemented with phosphate for more than $18 \mathrm{~h}$ showed significantly decreased rates of development beyond the 4-cell stage. The rate of development of the 2-cell embryos to the blasto- cyst stage was significantly reduced by exposure for more than $15 \mathrm{~h}$. No embryos developed to blastocyts beyond $21 \mathrm{~h}$ of exposure. The number of blastomeres in the blastocysts also decreased as the duration of exposure to phosphate increased.

\section{Discussion}

In this study, the development of 1-cell embryos that were flushed and washed with D-PBS (-) without no other treatment was inhibited. This inhibition was probably caused by phosphate carried over to the culture droplets. By repeated

Table 3. The effect of the duration of exposure to D-PBS (-) on development in vitro of rat 1-cell embryos

\begin{tabular}{cccccc}
\hline $\begin{array}{c}\text { Exposure } \\
\text { time } \\
\text { (min) }\end{array}$ & $\begin{array}{c}\text { 1-cell embryos } \\
\text { examined }\end{array}$ & $\begin{array}{c}\text { No. of embryos } \\
\text { developed to } \\
\text { 2-cell stage }\end{array}$ & $\begin{array}{c}\text { No. and (\%) of embryos developed to: } \\
\text { 24-cell stage at } \\
72 \mathrm{~h}\end{array}$ & $\begin{array}{c}\text { Mean no. of cells } \\
120 \mathrm{~h}\end{array}$ & $\begin{array}{c}\text { Meansts at } \\
\text { in blastocysts* } \\
\text { (no. examined) }\end{array}$ \\
\hline 0 & 27 & 27 & $26(96)$ & $12(44)$ & $20.0 \pm 3.5(9)$ \\
10 & 28 & 28 & $25(89)$ & $11(39)$ & $17.7 \pm 3.9(10)$ \\
20 & 31 & 31 & $31(100)$ & $16(52)$ & $19.4 \pm 4.4(14)$ \\
\hline
\end{tabular}

The numbers in parentheses indicate percentages relative to the initial number of 2-cell embryos.

The osmolarity of mHECM-1 was $285-286$ mOsm.

*: Mean \pm S.D.

Tabel 4. The effect of the duration of exposure to mHECM-1 supplemented with $1.19 \mathrm{mM}$ phosphate plus 5.56 $\mathrm{mM}$ glucose on development in vitro of rat 1-cell embryos

\begin{tabular}{cccccc}
\hline $\begin{array}{c}\text { Exposure } \\
\text { time } \\
(\text { min) }\end{array}$ & $\begin{array}{c}\text { 1-cell embryos } \\
\text { examined }\end{array}$ & $\begin{array}{c}\text { No. of embryos } \\
\text { developed to } \\
\text { 2-cell stage }\end{array}$ & $\begin{array}{c}\text { No. and (\%) of embryos developed to: } \\
\text { 24-cell stage at } \\
72 \mathrm{~h}\end{array}$ & $\begin{array}{c}\text { blastocysts at } \\
120 \mathrm{~h}\end{array}$ & $\begin{array}{c}\text { Mean no. of cells } \\
\text { in blastocysts* } \\
\text { (no. examined) }\end{array}$ \\
\hline 0 & 51 & 51 & $43(84)$ & $24(47)$ & $16.3 \pm 6.6(15)$ \\
30 & 51 & 47 & $45(96)$ & $28(60)$ & $16.6 \pm 4.6(16)$ \\
60 & 51 & 51 & $48(94)$ & $28(55)$ & $15.5 \pm 3.8(22)$ \\
\hline
\end{tabular}

The numbers in parentheses indicate percentages relative to the initial number of 2-cell embryos.

The osmolarity of mHECM-1 was 289 mOsm.

*: Mean \pm S.D.

Table 5. The effect of the duration of a brief exposure to mHECM-1 supplemented with $1.19 \mathrm{mM}$ phosphate plus $5.56 \mathrm{mM}$ glucose on development in vitro of rat 2-cell embryos

\begin{tabular}{|c|c|c|c|c|}
\hline \multirow{2}{*}{$\begin{array}{l}\text { Exposure } \\
\text { time } \\
(\mathrm{min})\end{array}$} & \multirow{2}{*}{$\begin{array}{c}\text { No. of } \\
\text { 2-cell embryos } \\
\text { examined }\end{array}$} & \multicolumn{2}{|c|}{ No. and $(\%)$ of embryos developed to: } & \multirow{2}{*}{$\begin{array}{l}\text { Mean no. of cells } \\
\text { in blastocysts* } \\
\text { (no. examined) }\end{array}$} \\
\hline & & $\begin{array}{c}\geq 4 \text {-cell stage at } \\
48 \mathrm{~h}\end{array}$ & $\begin{array}{c}\text { blastocysts at } \\
96 \mathrm{~h}\end{array}$ & \\
\hline 0 & 29 & $29 \quad(100)$ & $29 \quad(100)$ & $22.3 \pm 6.9 \quad(27)$ \\
\hline 30 & 28 & $26 \quad(93)$ & $26 \quad(93)$ & $21.1 \pm 7.3$ \\
\hline 60 & 29 & $29 \quad(100)$ & $29 \quad(100)$ & $21.8 \pm 6.0$ \\
\hline
\end{tabular}

The osmolarity of mHECM-1 was 289 mOsm.

*: Mean \pm S.D. 
Table 6. The effect of the duration of prolonged exposure to mHECM-1 supplemented with $1.19 \mathrm{mM}$ phosphate on development in vitro of rat 2-cell embryos

\begin{tabular}{|c|c|c|c|c|}
\hline \multirow{2}{*}{$\begin{array}{l}\text { Exposure } \\
\text { time } \\
(\mathrm{hr})\end{array}$} & \multirow{2}{*}{$\begin{array}{c}\text { No. of } \\
\text { 2-cell embryos } \\
\text { examined }\end{array}$} & \multicolumn{2}{|c|}{ No. and $(\%)$ of embryos developed to: } & \multirow{2}{*}{$\begin{array}{l}\text { Mean no. of cells } \\
\text { in blastocysts* } \\
\text { (no. examined) }\end{array}$} \\
\hline & & $\begin{array}{c}\geq 4 \text {-cell stage at } \\
48 \mathrm{~h}\end{array}$ & $\begin{array}{c}\text { blastocysts at } \\
96 \mathrm{~h}\end{array}$ & \\
\hline 0 & 107 & $107\left(100^{a}\right)$ & $104(97 a)$ & $29.4 \pm 8.5\left(92^{a}\right)$ \\
\hline 3 & 35 & $35(100 a)$ & $33(94 a)$ & $28.3 \pm 5.8(23 \mathrm{ab})$ \\
\hline 6 & 34 & $31\left(91^{a}\right)$ & $33(97 a)$ & $26.2 \pm 5.7\left(27^{b}\right)$ \\
\hline 9 & 47 & $46\left(98^{a}\right)$ & $45\left(96^{\mathrm{a}}\right)$ & $26.3 \pm 8.3\left(32^{b}\right)$ \\
\hline 12 & 51 & $51\left(100^{a}\right)$ & $46\left(90^{a}\right)$ & $26.7 \pm 8.7\left(38^{b}\right)$ \\
\hline 15 & 48 & $46\left(96^{a}\right)$ & $29\left(60^{b}\right)$ & $25.4 \pm 6.8\left(19^{b}\right)$ \\
\hline 18 & 49 & $33(67 b)$ & $11\left(22^{c}\right)$ & $19.9 \pm 5.3(9 c)$ \\
\hline 21 & 38 & $8\left(21^{c}\right)$ & $0\left(0^{d}\right)$ & \\
\hline 24 & 36 & $1\left(3^{d}\right)$ & $0\left(0^{d}\right)$ & \\
\hline
\end{tabular}

a-d Values with different superscripts within each column differ significantly $(\mathrm{P}<0.05)$.

The osmolarity of the medium was 289-292 mOsm.

*: Mean \pm S.D.

washings, the embryonic development was no longer inhibited. The assumed concentration of phosphate after these washings was below $1.0 \mathrm{fM}$. This results corresponded with earlier reports that said a concentration of phosphate below $10 \mathrm{nM}$ in HECM-1 did not inhibit rat embryonic development [4].

Embryonic development was examined by exposing embryos for a limited time to the medium containing phosphate. After washing, exposure for $20 \mathrm{~min}$ to D-PBS ( - ) did not inhibit subsequent embryonic development nor reduce the number of blastomeres in blastocysts. Exposure for 30 or $60 \mathrm{~min}$ to $\mathrm{mHECM}-1$ that contained 1.19 $\mathrm{mM} \mathrm{KH} \mathrm{HO}_{4}$ also did not decrease embryonic development rates of embryos at the 1-or 2-cell stage either to blastocysts nor beyond the 4-cell stage. Thus, when the exposure was brief, development was not inhibited.

The duration of exposure was gradually extended. Embryos at the 2-cell stage were exposed to mHECM-1 that contained $1.19 \mathrm{mM} \mathrm{KH_{2 }} \mathrm{PO}_{4}$ for 3, $6,9,12,15,18,21$ or $24 \mathrm{~h}$. When embryos were exposed to phosphate for more than $18 \mathrm{~h}$, the rates of development beyond the 4-cell stage and numbers of blastomeres per blastocyst decreased as the duration of exposure increased (Table 6; $\mathrm{P}<0.05$ ). The rate of development to the blastocyst stage was decreased by exposure to phosphate for more than $15 \mathrm{~h}$.

Rat embryonic development at the 2-cell stage was inhibited by phosphate in certain conditions. This inhibition was related to the duration of ex- posure. When embryos were exposed to phosphate for a marginal period $(15 \mathrm{~h})$, the development rate of the 2-cell stage to the 4-cell stage was not affected, but that to the blastocyst stage was significantly decreased. It is suggested that exposure to phosphate would delay some unknown metabolic steps necessary for the transition of embryos from the 2-cell to 4-cell stage as long as phosphate is present in the culture medium at effective concentration. The addition of an energy source to the culture medium allowed cleavage to the 4-cell stage [9]. This phosphate-caused delay of more than $15 \mathrm{~h}$ would have resulted in an irreversible cosequence, such as desynchronization of metabolic cascade, to further promote embryonic development beyond the 4-cell stage.

Mammalian embryos cultured in vitro cease development at a specific stage that is characteristic for each species. However, it is unclear how the mechanism of development is caused at a species, specific cell stage. In mice, the influences of ampulla on embryonic development are restricted to a specific period at the 2-cell stage in vitro [10]. In rats, the initiation of embryonic gene activation occurs at the late 2-cell stage and the first two cleavage divisions can occur in the absence of transcription [11].

Cultivation of embryos in vitro has been achieved for many mammalian species by adding growth factors, amino acids and energy sources to the medium and/or co-culture systems thereby enhancing embryonic development. However, such additions and systems have failed to overcome the develop- 
mental block in rat embryos. Using mHECM-1, which is free of phosphate and glucose, Kishi et al. were able to overcome the 2-cell block in rat embryos [3]. The presence of glucose and the absence of phosphate in IHECM-1 promoted rat embryonic development and concentrations of phosphate below $10 \mathrm{nM}$ in HECM-1 did not inhibit development [4]. Nevertheless, phosphate is present in many culture media. Phosphate provides buffering action and inorganic phosphate acts as an intermediate in energy metabolism that involves ATP and ADP. Furthermore, phosphate is present in the oviductal fluids of ewes, rabbits and sows in vivo [12-14]. The presence of phosphorus has also been reported in mouse oviducts [15]. Therefore, the mechanism of the developmental block in rat 2-cell embryos in the presence of phosphate is not well understood.

As previously stated HECM-1 is free of phosphate and glucose, and glucose reportedly inhibits the hamster embryonic development in the presence of phosphate $[2,16-21]$. Also, the conventional level of glucose in media reportedly inhibits embryonal development of mice [8, 22-24] and cattle $[25,26]$. However, both phosphate and glucose are present in the oviductal fluids of ewes, rabbits and sows in vivo [12-14]. It is unclear, there- fore, why the absence of glucose promotes embryonic development of some species in vitro. As reported previously, the development rate of rat embryos is increased by the presence of glucose [4] and the uptake of glucose by rat embryos increases during the blastocyst stage [27]. However, in the present experiment, glucose did not promote subsequent development when the embryos at 1-cell stage were exposure to phosphate following culture.

In conclusion, phosphate caused a developmental block in rat 2-cell embryos. This inhibition was caused by exposure to phosphate for $21 \mathrm{~h}$ at the 2cell stage. Because developmental block occurs during cultivation of many mammalian embryos in vitro and methods for overcoming the block differ among species, overcoming the block in rat embryos will contribute to future studies regarding mammalian embryonic development.

\section{Acknowledgments}

Part of this study was supported by a grant-inAid for Scientific Research (no. 02404018) from the Ministry of Education, Science and Culture, Japan.

\section{References}

1. Bavister BD. Role of oviductal secretions in embryonic growth in vivo and in vitro. Theriogenology 1988; 29: 143-154.

2. Schini SA, Bavister BD. Two-cell block to development of cultured hamster embryos is caused by phosphate and glucose. Biol Reprod 1988; 39: 11831192.

3. Kishi J, Noda Y, Narimoto K, Umaoka Y, Mori T. Block to development in cultured rat 1-cell embryos is overcome using medium HECM-1. Human Reprod 1991; 6: 1445-1448.

4. Miyoshi K, Funahashi H, Okuda K, Niwa K. Development of rat one-cell embryos in a chemically defined medium: effects of glucose, phosphate and osmolarity. J Reprod Fert 1994; 100: 21-26.

5. Whitten WK, Biggers JD. Complete development in vitro of the preimplantation stage of the mouse in a simple chemically defined medium. J Reprod Fert 1968; 17: 399-401.

6. Biggers JD, Whitten WK, Whittengham DG. The culture of mouse embryos in vitro. In: Daniel JC (ed.), Methods in Mammalian Embryology. San
Francisco: W H Freeman and Company; 1971: 86116.

7. Brinster RL, Biggers JD. In-vitro fertilization of mouse ova within the explanted fallopian tube. J Reprod Fert 1965; 10: 277-279.

8. Chatot CL, Ziomek CA, Bavister BD, Lewis JL, Torres I. An improved culture medium supports development of random-bred 1-cell mouse embryos in vivo. J Reprod Fert 1989; 86: 679-688.

9. Wada K, Horiuchi T, Sugawara S, Masaki J. Culture of rat eggs in vitro. Tohoku J Agric Res 1981; 32: 101-109.

10. Minami N, Utsumi K, Iritani A. Effect of low molecular weight oviductal factors on the development of mouse one-cell embryos in vitro. J Reprod Fert 1992; 96: 735-745.

11. Zernicka-Goetz M. Activation of embryonic genes during preimplantation rat development. Mol Reprod Dev 1994; 38: 30-35.

12. Iritani A, Gomes WR, VanDenmark NL. Secretion rates and chemical composition of oviduct and uterine fluids in ewes. Biol Reprod 1969; 1: 72-76. 
13. Iritani A, Nishikawa $\mathbf{Y}$, Gomes WR, VanDenmark NL. Secretion rates and chemical composition of oviduct and uterine fluids in rabbits. J Anim Sci 1971; 33: 829-835.

14. Iritani A, Sato E, Nishikawa Y. Secretion rates and chemical composition of oviduct and uterine fluids in sows. J Anim Sci 1974; 39: 582-588.

15. Borland RM, Hazra S, Biggers JD, Lechene CP. The elemental composition of the environments of the gametes and preimplantation embryo during the initiation of pregnancy. Biol Reprod 1977; 16: 147-157.

16. Bavister BD. Regulation of hamster preimplantation embryo development in vitro by glucose and phosphate. In: Heyner S, Wiley LM (eds.), Early Embryo Development and Paracrine relationships. New York: Alan R. Liss; 1990: 79-96.

17. Seshagiri PB, Bavister BD. Glucose inhibits development of hamster 8-cell embryos in vitro. Biol Reprod 1989; 40: 599-606.

18. Seshagiri PB, Bavister BD. Phosphate is required for inhibition by glucose of development hamster 8-cell embryos in vitro. Biol Reprod 1989; 40: 607614.

19. McKiernan SH, Bavister BD. Environment variables influencing in vitro development of hamster 2-cell embryos to blastocyst stage. Biol Reprod 1990; 43: 404-413.

20. Monis H, Bavister BD. Analysis of the inhibitory effect of inorganic phosphate on development of four-cell hamster embryos in vitro. J Exp Zool 1990; 256: 75-83.

21. Seshagiri PB, Bavister BD. Glucose and phosphate inhibit respiration and oxidative metabolism in cultured hamster eight-cell embryos: evidence for "crabtree effect". Mol Reprod Dev 1991; 30: 105111.

22. Lawitts JL, Biggers JD. Optimization of mouse embryo culture media using simplex methods. J Reprod Fert 1991; 91: 543-556.

23. Lawitts JL, Biggers JD. Overcoming the 2-cell block by modifying standard components in a mouse embryo culture medium. Biol Reprod 1991; 45: 245-251.

24. Lawitts JL, Biggers JD. Joint effects of sodium chloride, glutamine, and glucose in mouse preimplantation embryo culture media. Mol Reprod Dev 1992; 31: 189-194.

25. Takahashi Y, First NL. In vitro development of bovine one-cell embryos: influence of glucose, lactate, pyruvate, amino acids and vitamins. Theriogenology 1992; 37: 963-978.

26. Matsuyama K, Miyakoshi H, Fukui Y. Effect of glucose levels during the in vitro culture in synthetic oviduct fluid medium on in vitro development of bovine oocytes matured and fertilized in vitro. Theriogenology 1993; 40: 595-605.

27. Brison DR, Leese HJ. Energy metabolism in late preimplantation rat embryos. J Reprod Fert 1991; 93: 245-251. 